\title{
Rancang Bangun Sistem Informasi Verifikasi Dan Validasi Data Pengajuan Tender Berbasis Web
}

\author{
Rahmat Gunawan', Yahya Suherman ${ }^{2}$, Seno Satrio Wibowo ${ }^{3}$ \\ ${ }^{1,2,3}$ Manajemen Informatika, STMIK Rosma, Karawang \\ E-mail: rahmat@rosma.ac.id
}

\begin{abstract}
The magnitude of the benefits and advantages of information technology can now be utilized by local governments in assisting with work, declaring/processing important data and services as expected by the community. One of the factors that support the success of government programs in service is the process of data verification and validation. Currently, the Regional Government of Karawang Regency, especially in the goods and services section, is experiencing problems in the verification and validation process of tender submission data, which takes time, and often forgets the location for storing the tender submission data file. So with this information system, it will help the goods and services party reduce data loss, making it more efficient in reporting. This information system for verification and validation of tender submission data is Web-based using PHP and MySQL. The design of this application uses the SDLC Waterfall methodology. And the database used is MYSQL which will be performed on the windows operating system.
\end{abstract}

Keywords: MySQL, Web, Design, tender

\begin{abstract}
Abstrak
Menyadari akan besarnya manfaat serta keunggulan teknologi informasi saat ini dapat di manfaatkan oleh pemerintah daerah dalam membantu pekerjaan, pemrosesan/pengolahan data-data penting serta pelayanan sebagaimana diharapkan oleh masyarakat. Salah satu faktor yang mendukung keberhasilan program pemerintahaan dalam pelayanan adalah proses verifikasi dan validasi data. Saat ini Pemerintahan Daerah Kabupaten Karawang khususnya pada bagian barang dan jasa mengalami kendala pada proses verifikasi dan validasi data pengajuan tender yang cukup memakan waktu, serta sering terjadi kelupaan lokasi penyimpanan file data pengajuan tender tersebut. Maka dengan ada nya sistem informasi ini akan membantu pihak barang dan jasa meminimalisir kehilangan data dan pelaporan data yang cepat, sehingga lebih efisien. Sistem informasi verifikasi dan validasi data pengajuan tender ini berbasis Web menggunakan php dan MySQL. Perancangan aplikasi ini menggunakan metodologi SDLC Waterfall. Dan Basis data yang digunakan adalah MysSQL yang akan dilakukan pada sistem operasi windows.
\end{abstract}

Kata Kunci: MySQL, Web, Perancangan, tender

\section{Article History :}

Received 30, November, 2021

Revised 14, Januari, 2022

Accepted 15, Januari, 2022

\section{Corresponding Author:}

Nama Penulis, Rahmat Gunawan

Departemen, Manajemen Informatika

Instansi, STMIK Rosma

Alamat. Jln. Kertabumi No 62 Karawang

Email Penulis.rahmat@rosma.ac.id 


\section{Pendahuluan}

Setiap orang membutuhkan informasi untuk menunjang aktivitas mereka, sehingga berusaha untuk mengakses informasi secepat mungkin. Perkembangan teknologi informasi diseluruh dunia telah membuat hidup manusia menjadi semakin mudah. Terutama sejak diciptakannya jaringan internet, komunikasi menjadi semakin tidak terbatas dan tanpa hambatan, baik hambatan geografis maupun hambatan waktu.

Menyadari akan besarnya manfaat serta keunggulan teknologi informasi saat ini dapat di manfaatkan oleh pemerintah daerah dalam membantu pekerjaan, pemrosesan/pengolahan data-data penting serta pelayanan sebagaimana diharapkan oleh masyarakat. Dengan adanya komputerisasi diharapkan dapat meningkatkan efisiensi administrasi Pemerintah Daerah sekaligus menampung semakin banyaknya kebutuhan pengolahan data.

Pemerintahan Daerah Kabupaten Karawang khususnya pada bagian barang dan jasa mengalami kendala pada proses verifikasi dan validasi data pengajuan tender. Mengingat bahwa ada banyak pihak yang mengandalkan informasi dari data pengajuan tender yang dihasilkan oleh bagian barang dan jasa akan digunakan oleh beberapa pihak yang berkepentingan sebagai dasar untuk pengambilan keputusan. Data pengajuan tender harus bisa diverifikasi dan divalidasi serta disajikan kapan saja ketika ada pihak yang membutuhkan data pengajuan tender tersebut. Permasalahan yang sedang dihadapi oleh bagian barang dan jasa adalah dalam hal verifikasi dan validasi data pengajuan tender yang cukup memakan waktu, serta sering terjadi kehilangan berkas kelengkapan data pengajuan tender yang masih berbentuk hardcopy.

Oleh sebab itu, Pemerintah Daerah Kabupaten Karawang bagian barang dan jasa perlu mengubah dari sistem verifikasi dan validasi yang manual menjadi sistem verifikasi dan validasi yang terkomputerisasi.

\section{Tinjauan Pustaka}

\subsection{Sistem Informasi}

Analisis dan Perancangan Sistem Informasi Menggunakan Model Terstruktur dan UML [1] sistem informasi merupakan suatu kumpulan dari komponen-komponen dalam organisasi yang berhubungan dengan proses penciptaan aliran informasi.

Kualitas Penerapan Sistem Informasi Akuntansi Manajemen Pada Entitas Sektor Publik [2] sistem informasi yaitu suatu kegiatan yang di dalamnya terjadi pengumpulan, pemrosesan, penyimpanan, analisis, dan menyebarkan informasi demi tercapainyna suatu tujuan.

Berdasarkan pendapat diatas, penulis menyimpulkan sistem informasi adalah rangkaian prosedur kerja, informasi, orang dan teknologi di mana data dikelompokan, diproses menjadi informasi serta didistribusikan untuk mencapai tujuan dalam sebuah organisasi.

\subsection{E-Government}

E-government atau kadang sering disingkat menjadi e-gov adalah istilah yang menyatakan penggunaan teknologi informasi untuk melakukan transformasi hubungan dengan masyarakat, bisnis, sesama badan pemerintah, dan pegawai[3]. Menurut Instruksi Presiden Nomor 3 Tahun 2003, strategi pengembangan egovernment adalah sebagai berikut.

1. Mengembangkan sistem pelayanan yang andal dan terpercaya, serta terjangkau oleh masyarakat luas.

2. Menata sistem manajemen dan proses kerja pemerintah dan pemerintah daerah otonom secara holistik.

3. Memanfaatkan teknologi informasi secara optimal.

4. Meningkatkan peran serta dunia usaha dan mengembangkan industri 
telekomunikasi dan teknologi informasi.

5. Mengembangkan kapasitas sumber daya manusia baik pada pemerintah maupun pemerintah daerah otonom, disertai dengan meningkatkn e-literacy masyarakat.

6. Melaksanakan pengembangan secara sistematik melalui tahapan-tahapan yang realistik dan terukur.

\subsection{Basis Data}

Basis data adalah media untuk menyimpan data agar dapat diakses dengan mudah dan cepat [4].

Basis data atau database adalah suatu pengorganisasian sekumpulan data yang saling terkait sehingga memudahkan aktivitas untuk memperoleh informasi [5].

\subsection{MySQL}

mysql adalah sebuah sistem manajemen database relasi (Relational Database Management System) yang bersifat "terbuka" (open source). Terbuka maksudnya adalah mysql dapat didownload oleh siapa saja [6].

mysql adalah salah satu jenis database server yang sangat terkenal dan banyak digunakan untuk membangun aplikasi web yang menggunakan database sebagai sumber dan pengolahan datanya[6].

\subsection{Web}

Website atau disingkat web dapat diartikan sekumpulan halaman yang terdiri dari beberapa laman yang berisi informasi dalam bentuk data digital baik berupa text, gambar, video, audio, dan animasi lainnya yang disediakan melalui jalur koneksi internet [7].

Sistem pengaksesan informasi dalam internet yang paling dikenal adalah World Wide Web (WWW) atau biasa dikenal dengan istilah web. Pertama kali diciptakan pada tahun 1991 di CERN, Laboratorium Fisika Partikel Eropa, Jenewa, Swiss. Tujuan awalnya adalah untuk menciptakan media yang mudah untuk berbagai informasi di antara para fisikawan dan ilmuwan[8].

\subsection{PHP}

PHP merupakan skrip yang berjalan di server dan sangat populer di lingkungan Linux. Saat ini, PHP dapat berjalan pada berbagai platform, dari UNIX hingga Windows [9].

PHP adalah bahasa scripting server dan alat yang ampuh untuk membuat halaman web dinamis dan interaktif [9].

\subsection{Bootstrap}

Bootsrtrap adalah front-end framework yang bagus dan luar biasa yang mengedepankan tampilan untuk mobiledevice (handphone, smartphone, d.ll) guna mempercepat dan mempermudah pengembangan website[10].

Bootsrtrap merupakan salah satu framework HTML, CSS, dan JS yang cukup banyak digunakan oleh para pengembang web[11].

\subsection{Pengertian Metode Waterfall}

Model waterfall adalah model klasik yang bersifat sistematis, berurutan dalam membangun software. Nama model ini sebenarnya adalah "Linear Sequential Model". Model ini sering disebut juga dengan "classic life cycle" atau metode waterfall. Model ini termasuk ke dalam model generic pada rekayasa perangkat lunak dan pertama kali diperkenalkan oleh Winston Royce sekitar tahun 1970 sehingga sering dianggap kuno, tetapi merupakan model yang paling banyak dipakai dalam Software Engineering (SE). Model ini melakukan pendekatan secara sistematis dan berurutan. Disebut dengan waterfall 
karena tahap demi tahap yang dilalui harus menunggu selesainya tahap sebelumnya dan berjalan berurutan.
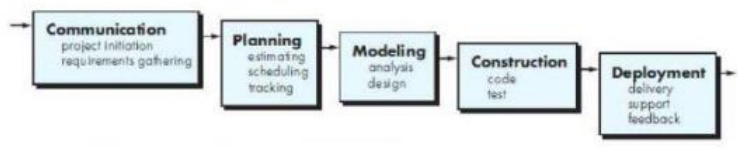

\section{Gambar 1. Model Waterfall}

\subsection{UML (Unified Modeling Language)}

Unified Modeling Language (UML) versi 2.0 adalah sekumpulan konversi pemodelan yang digunakan untuk menentukan atau menggambarkan sebuah sistem software yang terkait dengan objek.

UML mulai diperkenalkan oleh Object Management Group, sebuah organisasi yang telah mengembangkan model, teknologi, dan standar OOP sejak tahun 1980-an. Sekarang, UML sudah mulai banyak digunakan oleh para praktisi OOP. UML juga merupakan dasar bagi design tools berorientasi objek pada IBM.

UML dikembangkan sebagai suatu alat untuk analisis dan desain berorientasi objek oleh Grady Booch, Jim Rumbaugh, dan Ivar Jacobson[12].

UML menyediakan tiga belas macam diagram untuk memodelkan aplikasi berorientasi objek, empat macam diagram yang akan digunakan dalam penelitian ini yaitu:

1. Use case diagram menggambarkan interaksi antara sistem internal, system eksternal, dan user. Dengan kata lain, secara grafik menjelaskan siapa yang menggunakan sistem, dan dengan cara apa user berinteraksi dengan sistem.

2. Activity diagram menggambarkan alur sequential dari aktivitas sebuah proses bisnis atau use case. Bisa juga digunakan untuk memodelkan logika yang digunakan sistem.

3. Class diagram menggambarkan struktur objek sistem. Menunjukkan kelas yang menjadi komponen dari sistem, serta hubungan antar kelas.

4. Sequence diagram menggambarkan bagaimana objek berinteraksi melalui pengiriman pesan (message) dalam pengeksekusian sebuah use case atau operasi tertentu.

\subsection{Pengadaan Barang dan jasa}

Pasal 1 ayat 1 peraturan presiden No. 54 tahun 2010 sebagaimana diubah terakhir dengan peraturan presiden No. 70 tahun 2012 tentang pengadaan barang atau jasa pemerintah adalah kegiatan untuk memperoleh barang atau jasa oleh kementrian atau lembaga atau satuan kerja perangkat daerah atau institusi lainnya yang prosesnya dimulai dari perencanaan kebutuhan sampai diselesaikannya seluruh kegiatan untuk memperoleh barang atau jasa.

\section{Metode}

Metodologi penelitian yang digunakan dalam penelitian ini menggunakan Design Science Research Methodology (DSRM). Penggunaan metodologi ini difokuskan pada solusi permasalahan dan pengembangan system.

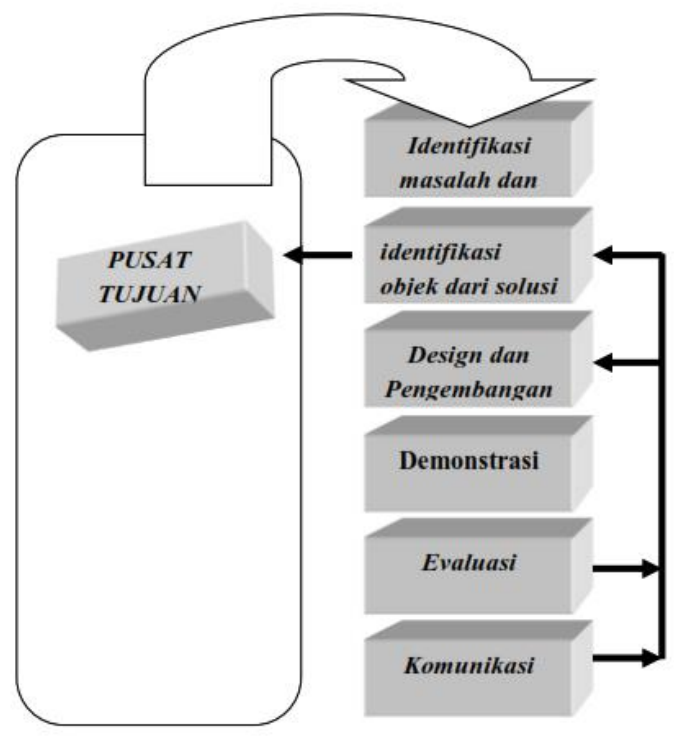

Gambar 2. Tahapan Metodologi

Penelitian 
1. Identifikasi Masalah dan Motivasi Melakukan identifikasi masalah yang terjadi pada penelitian dengan beberapa teknik pengumpulan data yaitu wawancara. Dalam hal ini adalah mengidentifikasi semua proses bisnis yang terjadi pada Pemerintah Daerah Kabupaten Karawang bagian Pengadaan Barang dan Jasa. Untuk membangun system verifikasi dan validasi pengajuan tender. Pada tahapan ini merupakan titik awal penelitian. Semua proses bisnis akan dirangkum dan didapatkan solusi dan dikonsepkan sesuai dengan proses bisnis yang terjadi di organisasi.

2. Mendefinisikan Obyek dari Solusi Permasalahan

Pada tahapan ini mendefinisikan solusi dari permasalahan dengan melakukan studi literatur, untuk memperoleh teoriteori dan konsep dari metode yang digunakan yaitu

3. Design dan Pengembangan

Tahapan ini dilakukan Design berupa rancangan dan model dari Analisa yang dilakukan pada tahap sebelumnya. Selanjutnya akan dilakukan pengembangan dengan Use Case Diagram untuk proses alur system aplikasi, Activity Diagram, Sequence Diagram dan Class Diagram.

4. Demonstrasi (Implementasi)

Tahap ini melakukan Implementasi terhadap rancangan pengembangan. Pada pase ini merupakan pase pengkodingan kedalam teknologi yang digunakan untuk membuat aplikasi verifikasi dan validasi pengajuan tender berbasis web.

5. Evaluasi

Setelah Implementasi dilakukan untuk mengganalisa dari model yang dibuat, selanjutnya data hasil analisa akan dilakukan pengujian dengan Black Box.
Komunikasi pada tahapan ini adalah bentuk laporan dari hasil penelitian yang berupa sebuah kesimpulan untuk dipublikasikan. Isi kesimpulan tersebut dapat berupa penilaian terhadap model yang telah dibuat dan hasil analisis dari bentuk pemodelan yang telah ujikan.

\section{Hasil dan Pembahasan}

Analisis terhadap suatu sistem sangat diperlukan untuk mengikuti kegiatankegiatan yang sedang berjalan di dalam suatu sistem. Tujuan mengetahui kegiatankegiatan tersebut adalah untuk memahami dan mengerti alur sistem serta hambatan yang terdapat di dalam sistem tersebut. Pada tahap ini yang perlu dilakukan adalah analisis terhadap sistem yang sedang berjalan dan bagaimana aliran dokumen sistem yang berjalan.

\subsection{Analisis Sistem Yang Berjalan}

Analisa sistem berjalan dapat dilihat pada gambar flowchart di bawah ini :

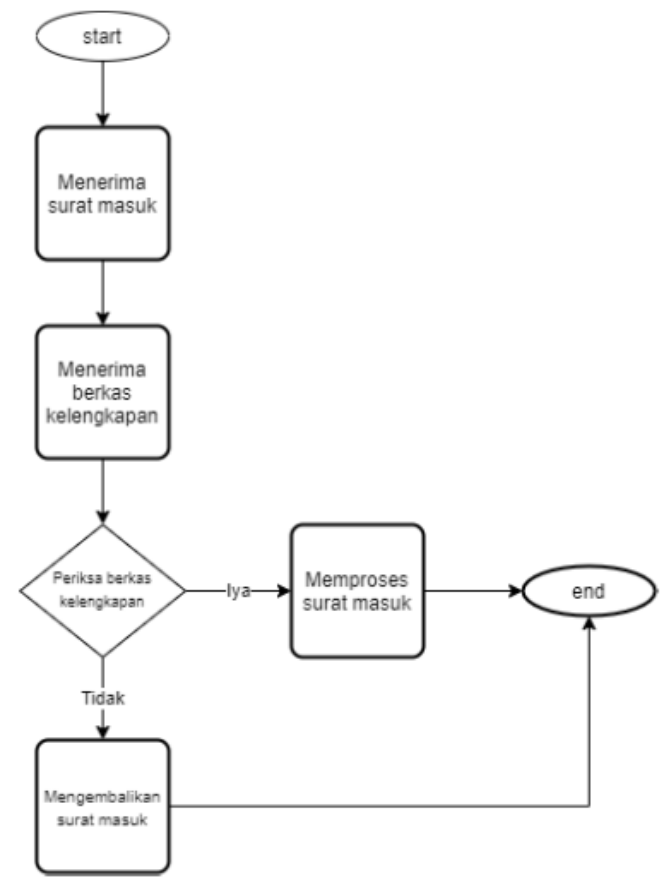

Gambar 1. Analisis Sistem Yang Berjalan 


\subsection{Perancangan Sistem}

Sesuai dengan metode perancangan sistem yang digunakan yaitu Unified Modeling Language (UML). Maka sistem yang baru akan digambarkan pada use case diagram, activity diagram, class diagram, dan sequence diagram.

\section{Use Case Diagram}

Pada sistem informasi verifikasi dan validasi data pengajuan tender di Pemerintah Daerah Kabupaten Karawang Bagian Pengadaan Barang dan Jasa terdapat use case diagram yang bertujuan untuk mendeskripsikan tahapan-tahapan dan menggambarkan tindakan apa saja yang dapat aktor lakukan terhadap sistem informasi laporan realisasi pengadaan barang dan jasa.

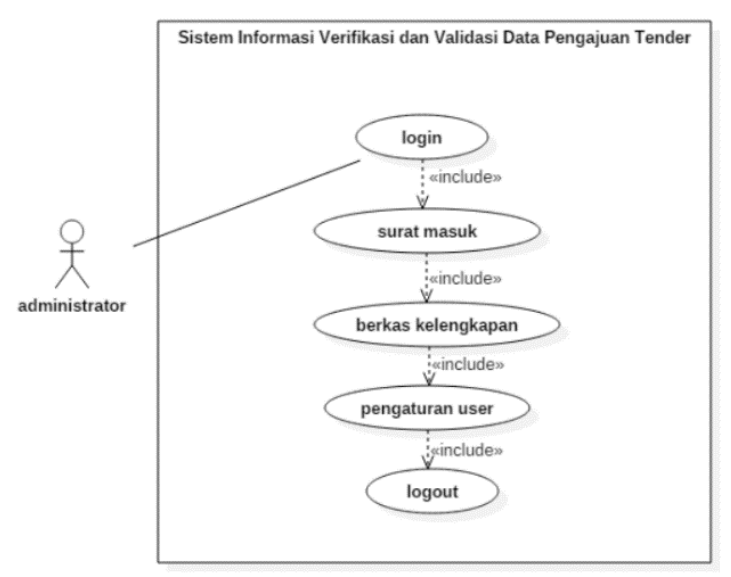

Gambar 2. Use Case Diagram Admin

\section{Definisi Aktor}

Berikut adalah definisi aktor yang ada di dalam sistem informasi verifikasi dan validasi data pengajuan tender. Pada sistem ini terdiri dari 1 aktor, yang di paparkan

dalam tabel berikut antara lain :
Tabel 1. Defini Aktor

\begin{tabular}{c|l|l}
\hline No. & \multicolumn{1}{|c|}{ Aktor } & \multicolumn{1}{c}{ Keterangan } \\
\hline 1. & Administrator & $\begin{array}{l}\text { Pengguna dengan hak akses penuh } \\
\text { dalam sistem informasi. }\end{array}$ \\
\hline
\end{tabular}

\section{Definisi Use Case}

Berikut adalah definisi use case yang digunakan dalam sistem informasi verifikasi dan validasi data pengajuan tender yaitu :

Tabel 2. Definisi Use Case

\begin{tabular}{c|l|l}
\hline No. & \multicolumn{1}{|c|}{ Use Case } & \multicolumn{1}{c}{ Deskripsi } \\
\hline 1. & Login & $\begin{array}{l}\text { Merupakan proses masuk ke dalam } \\
\text { sistem informasi dengan memasukkan } \\
\text { username dan password untuk } \\
\text { mendapatkan hak akses. }\end{array}$ \\
\hline 2. & Surat Masuk & $\begin{array}{l}\text { Merupakan proses penambahan data } \\
\text { surat masuk. }\end{array}$ \\
\hline 3. & Berkas Kelengkapan & $\begin{array}{l}\text { Merupakan proses penambahan data } \\
\text { berkas kelengkapan surat masuk. }\end{array}$ \\
\hline 4. & Pengaturan User & Merupakan proses penambahan user. \\
\hline 4. & Logout & $\begin{array}{l}\text { Merupakan proses keluar dari sistem } \\
\text { informasi. }\end{array}$ \\
\hline
\end{tabular}

\section{Skenario Use Case Login}

Tabel 3. Skenario Use Case Login

\begin{tabular}{|c|c|c|c|c|}
\hline Nama Use Case & \multicolumn{4}{|c|}{ Login } \\
\hline $\begin{array}{l}\text { Skenario Deskripsi } \\
\text { Singkat }\end{array}$ & \multicolumn{4}{|c|}{$\begin{array}{l}\text { Sebelum masuk ke dalam sistem aktor harus memasukkan } \\
\text { username dan password kemudian klik tombol login }\end{array}$} \\
\hline Aktor & \multicolumn{4}{|c|}{ Administrator } \\
\hline Kondisi Sebelum & \multicolumn{4}{|l|}{ - } \\
\hline Kondisi Sesudah & \multicolumn{4}{|c|}{ Aktor dapat menggunakan fasilitas sistem } \\
\hline \multirow[t]{2}{*}{ Aliran Aktivitas } & & Aktor & & Sistem \\
\hline & 1. & $\begin{array}{l}\text { Memasukkan } \\
\text { username dan } \\
\text { password lalu klik } \\
\text { tombol login }\end{array}$ & & $\begin{array}{l}\text { Menampilkan halaman } \\
\text { utama }\end{array}$ \\
\hline $\begin{array}{l}\text { Penangkapan } \\
\text { Kondisi Kesalahan }\end{array}$ & 1. & \multicolumn{3}{|c|}{$\begin{array}{l}\text { Apabila login gagal maka sistem akan menampilkan } \\
\text { pesan bahwa gagal login }\end{array}$} \\
\hline
\end{tabular}

\section{Skenario Use Case Surat Masuk}

Tabel 4. Skenario Use Case Surat Masuk 


\begin{tabular}{|c|c|c|c|c|}
\hline Nama Use Case & \multicolumn{4}{|c|}{ Surat Masuk } \\
\hline $\begin{array}{l}\text { Skenario Deskripsi } \\
\text { Singkat }\end{array}$ & \multicolumn{4}{|c|}{$\begin{array}{l}\text { Sistem akan menampilkan data surat masuk, tambah, ul } \\
\text { dan hapus data surat masuk }\end{array}$} \\
\hline Aktor & \multicolumn{4}{|c|}{ Administrator } \\
\hline Kondisi Sebelum & \multicolumn{4}{|l|}{ - } \\
\hline Kondisi Sesudah & \multicolumn{4}{|c|}{$\begin{array}{l}\text { Adanya perubahan data yang tersimpan ke dalam datal } \\
\text { sistem }\end{array}$} \\
\hline \multirow[t]{5}{*}{ Aliran Aktivitas } & & Aktor & & Sistem \\
\hline & 1. & $\begin{array}{l}\text { Memilih menu surat } \\
\text { masuk }\end{array}$ & 1. & $\begin{array}{l}\text { Menampilkan data s } \\
\text { masuk }\end{array}$ \\
\hline & 2. & $\begin{array}{l}\text { Menambah data surat } \\
\text { masuk }\end{array}$ & 2. & $\begin{array}{l}\text { Menampilkan } f \\
\text { tambah data surat mas }\end{array}$ \\
\hline & 3. & $\begin{array}{l}\text { Merubah data surat } \\
\text { masuk }\end{array}$ & 3. & $\begin{array}{l}\text { Menampilkan data } \mathrm{s} \\
\text { masuk yang akan diub }\end{array}$ \\
\hline & 4. & $\begin{array}{l}\text { Menghapus data surat } \\
\text { masuk }\end{array}$ & 4. & $\begin{array}{l}\text { Menampilkan data } \mathrm{s} \\
\text { masuk yang akan diha }\end{array}$ \\
\hline $\begin{array}{l}\text { Penangkapan } \\
\text { Kondisi Kesalahan }\end{array}$ & 1. & \multicolumn{3}{|c|}{$\begin{array}{l}\text { Apabila administrator memilih perintah batal maka } \\
\text { tidak akan tersimpan }\end{array}$} \\
\hline
\end{tabular}

\section{Skenario Use Case Berkas} Kelengkapan

Tabel 5. Skenario Use Case Berkas Kelengkapan

\begin{tabular}{|c|c|c|c|c|}
\hline Nama Use Case & \multicolumn{4}{|c|}{ Berkas Kelengkapan } \\
\hline $\begin{array}{l}\text { Skenario Deskripsi } \\
\text { Singkat }\end{array}$ & \multicolumn{4}{|c|}{$\begin{array}{l}\text { Sistem akan menampilkan berkas kelengkapan, tambah, } \\
\text { ubah, dan hapus laporan }\end{array}$} \\
\hline Aktor & \multicolumn{4}{|c|}{ Administrator } \\
\hline Kondist Sebelum & \multicolumn{4}{|l|}{ - } \\
\hline Kondisi Sesudah & \multicolumn{4}{|c|}{$\begin{array}{l}\text { Adanya perubahan data yang tersimpan ke dalam database } \\
\text { sistem }\end{array}$} \\
\hline \multirow[t]{5}{*}{ Aliran Aktivitas } & & Aktor & & Sistem \\
\hline & 1. & $\begin{array}{l}\text { Memilih menu berkas } \\
\text { kelengkapan }\end{array}$ & 1. & $\begin{array}{l}\begin{array}{l}\text { Menampilkan } \quad \text { berkas } \\
\text { kelengkapan }\end{array} \\
\end{array}$ \\
\hline & 2. & $\begin{array}{l}\text { Menambah berkas } \\
\text { kelengkapan }\end{array}$ & 2. & $\begin{array}{lr}\begin{array}{l}\text { Menampilkan } \\
\text { tambah }\end{array} & \text { form } \\
\text { kelengkapan } & \text { berkas }\end{array}$ \\
\hline & 3. & $\begin{array}{l}\text { Merubah berkas } \\
\text { kelengkapan }\end{array}$ & 3. & $\begin{array}{l}\text { Menampilkan form ubah } \\
\text { berkas kelengkapan }\end{array}$ \\
\hline & 4. & $\begin{array}{l}\text { Menghapus berkas } \\
\text { kelengkapan }\end{array}$ & 4. & $\begin{array}{l}\text { Menampilkan berkas } \\
\text { kelengkapan yang akan } \\
\text { dihapus }\end{array}$ \\
\hline $\begin{array}{l}\text { Penangkapan } \\
\text { Kondisi Kesalahan }\end{array}$ & \multicolumn{4}{|c|}{$\begin{array}{l}\text { 1. Apabila aktor memilih perintah batal maka data tidak } \\
\text { akan tersimpan }\end{array}$} \\
\hline
\end{tabular}

\section{Activity Diagram Login}

Activity diagram di bawah ini digunakan untuk mengetahui alur login. Berikut ini activity diagram untuk login :

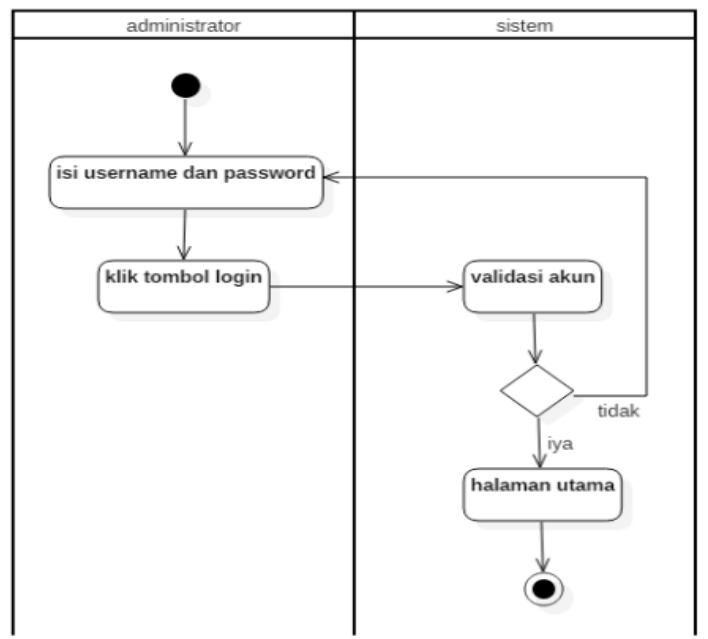

Gambar 3. Activity Diagram Login

\section{Activity Surat Masuk}

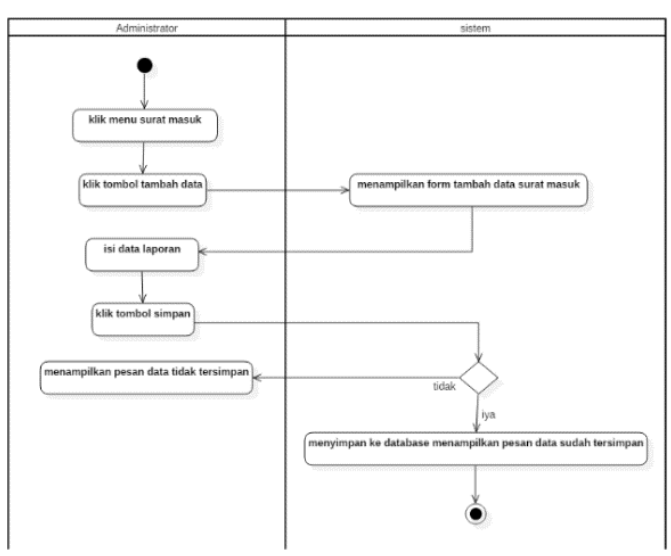

Gambar 4. Activity Surat Masuk

\section{Activity Berkas Kelengkapan}

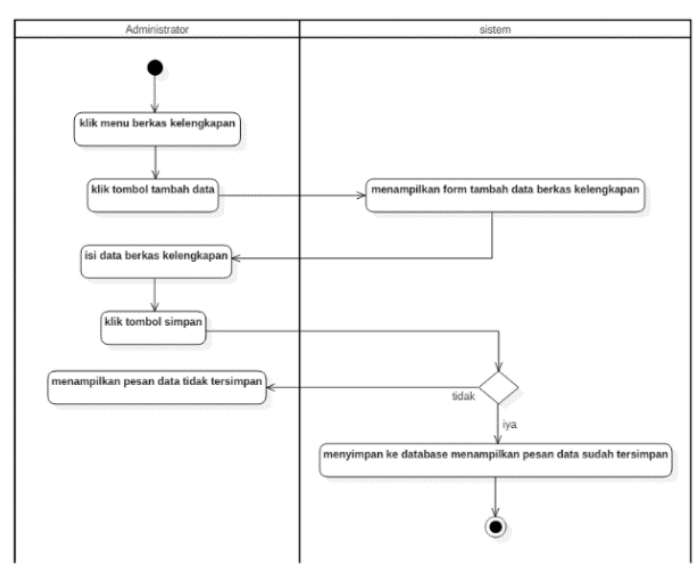

Gambar 5. Activity Berkas

Kelengkapan

10. Sequence Berkas Kelengkapan 


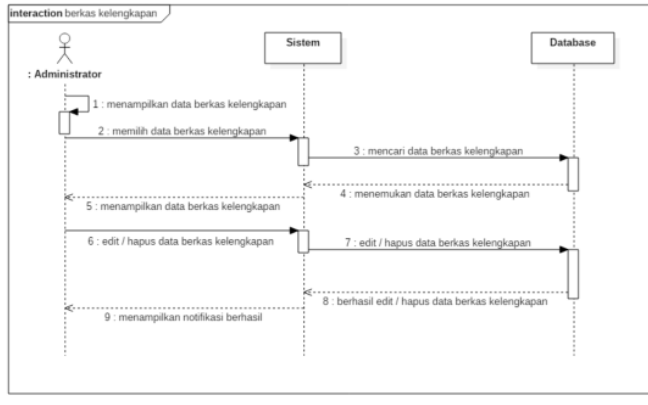

Gambar 6. Sequence Berkas Kelengkapan

\subsection{Perancangan Antar Muka}

Perancangan antarmuka ini akan menggambarkan tampilan user interface sistem informasi verifikasi dan validasi data pengajuan tender. Hal ini bermasksud untuk memberikan gambaran sederhana kepada user tentang user interface dari sistem informasi laporan realisasi pengadaan barang dan jasa.

\section{Rancangan Halaman Login}

Rancangan halaman login ialah rancangan halaman yang digunakan untuk masuk ke dalam sistem informasi verifikasi dan validasi data pengajuan tender dengan cara memasukkan username dan password, di bawah ini rancangan antar muka halaman login :

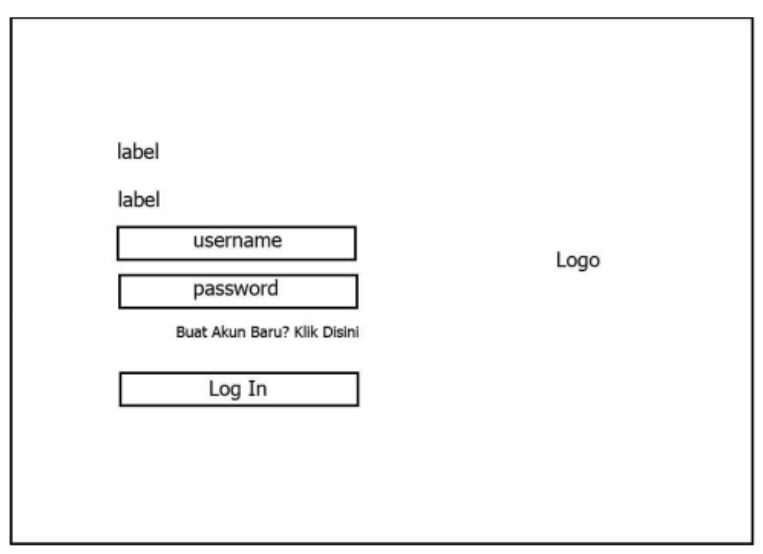

Gambar 7. Rancangan Halaman Login

2. Rancangan Halaman Tabel Data
Rancangan halaman tabel data ialah rancangan halaman yang digunakan ketika user klik salah satu menu seperti menu data surat masuk, berkas kelengkapan, dan pengaturan user. Di bawah ini rancangan antar muka halaman utama :

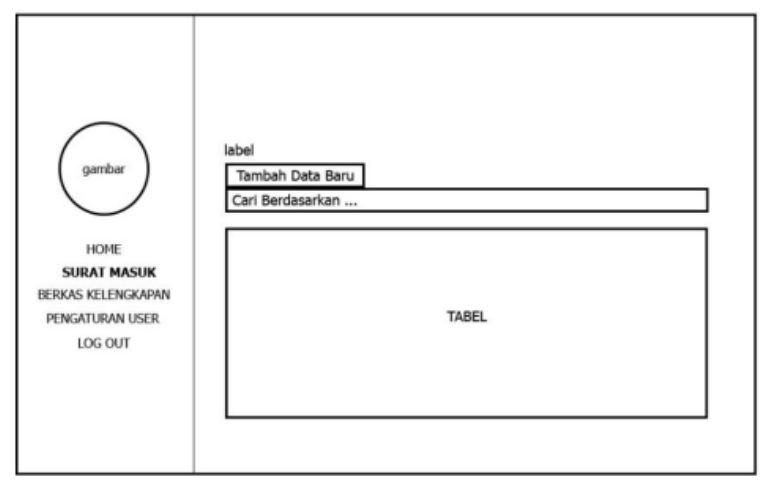

Gambar 8. Rancangan Halaman Tabel Data

\subsection{Implementasi}

Tahap implementasi merupakan tahapan lanjutan dari tahap perancangan, analisis, dan desain sistem yang bertujuan menerapkan sistem yang telah dirancang pada tahap sebelumnya baik perangkat lunak maupun perangkat keras yang digunakan. Berikut ini merupakan perangkat yang digunakan untuk merancang dan mengimplementasikan sistem informasi verifikasi dan validasi data pengajuan tender :

1. perangkat keras atau hardware;

2. perangkat lunak atau software;

3. pengguna atau user;

\subsection{Implementasi Antarmuka}

Implementasi antarmuka merupakan tahap pengimplementasian dari tahap desain dan analisis sistem. Berikut ini adalah implementasi antarmuka dari sistem informasi verifikasi dan validasi data pengajuan tender :

\section{Halaman Login}




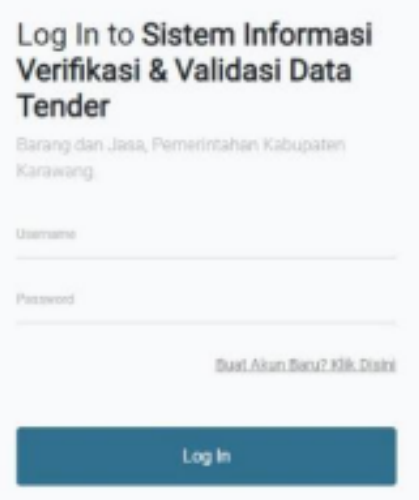

Gambar 9. Halaman Login

2. Halaman Data Surat Masuk

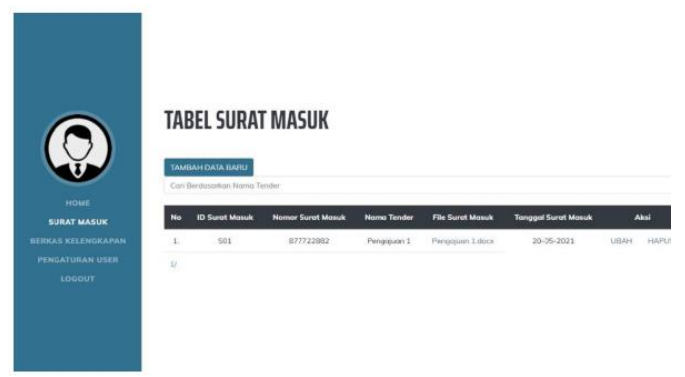

Gambar 10. Halaman Data Surat Masuk

\section{Halaman Berkas Kelengkapan}

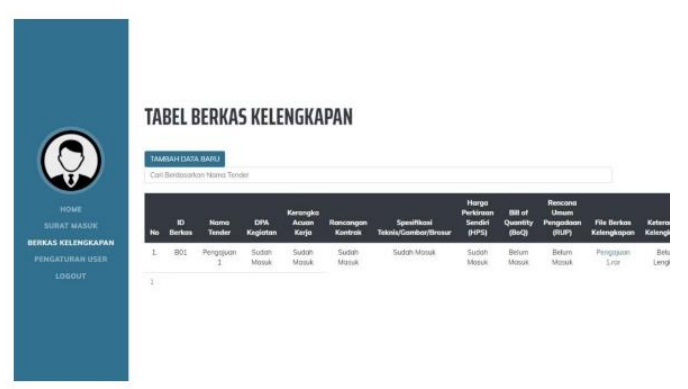

Gambar 11. Halaman Berkas Kelengkapan

\subsection{Pengujuan Perangkat Lunak}

Pengujian dilakukan untuk menjamin bahwa perangkat lunak telah berfungsi dengan baik dan sesuai dengan tujuan dari penelitian ini. Pada tahap pengajuan penulis menggunakan metode black box testing.

Black Box Testing
Tabel 5. Black Box Testing

\begin{tabular}{c|l|l|c|c}
\hline No. & Nama Fungsi & \multicolumn{1}{|c|}{ Kriteria } & Hasil Test & Keterangan \\
\hline 1. & Login & Berhasil login & Valid & OUKPBJ \\
\hline 2. & $\begin{array}{l}\text { Lihat Data } \\
\text { Surat Masuk }\end{array}$ & $\begin{array}{l}\text { Menampilkan } \\
\text { data Surat } \\
\text { Masuk }\end{array}$ & Valid & Valid \\
\hline 3. & $\begin{array}{l}\text { Tambah Data } \\
\text { Surat Masuk }\end{array}$ & $\begin{array}{l}\text { Berhasil } \\
\text { menambahkan } \\
\text { data Surat } \\
\text { Masuk }\end{array}$ & & \\
\hline
\end{tabular}

\section{Penutup}

Berdasarkan uraian pada pembahasan dan hasil penelitian di atas, maka dapat diambil beberapa kesimpulan sebagai berikut :

1. Sistem informasi verifikasi dan validasi data pengajuan tender berbasis web ini dapat mempercepat proses verifikasi dan validasi data pengajuan tender.

2. Sistem informasi verifikasi dan validasi data pengajuan tender berbasis web ini dapat mempermudah admin penerima surat masuk dalam menyimpan berkas kelengkapan data pengajuan tender dalam bentuk softcopy, sehingga dapat terhindar dari kehilangan berkas kelengkapan data pengajuan tender, serta memudahkan proses verifikasi berkas kelengkapan data pengajuan tender.

\section{Daftar Pustaka}

[1] Abdul Kadir, "Pengenalan Sistem Informasi Edisi Revisi," Edisi Revisi. 2014.

[2] S. Mulyani, Metode Analisis dan Perancangan sistem. Bandung: Abdi Sistematika, 2016.

[3] E. Sutanta and A. Ashari, "Pemanfaatan Database Kependudukan Terdistribusi Pada Ragam Aplikasi Sistem Informasi Di Pemerintah Kabupaten/Kota," $J$. Sist. Inf. Teknol. Inf. (SISFOTENIKA), STMIK Pontianak, Kalimantan Barat, ISSN 2087-7897, vol. 2, no. 1, 2012.

[4] Fathansyah, Basis Data. Bandung: 
Informatika, 2015.

[5] R. Gunawan and A. M. Yusuf, "APLIKASI PERBAIKAN AKTA KELAHIRAN DAN SMS GATEWAY BERBASIS WEB PADA DINAS KEPENDUDUKAN DAN PENCATATAN SIPIL KABUPATEN KARAWANG," vol. 6, no. 2, pp. 221-229, 2021.

[6] E. Ratnasari, "Pengertian Dan Fungsi Xampp," Ilmuti.Org, 2018.

[7] J. Enterprise, Membuat Website PHP dengan Codeigniter. Jakarta: PT Elex Media Komputindo, 2015.

[8] H. Wan and C. Horvath, Dave Chaffey, vol. 410, no. 1. 2015.

[9] J. Enterprise, PHP Komplet. Jakarta: PT Elex Media Komputindo, 2017.

[10] Z. A. R. \& S. Community, Bootstrap Design Framework. Jakarta: PT Elex Media Komputindo, 2015.

[11] D. T. Hoang, O. Chernomor, A. Von Haeseler, B. Q. Minh, and L. S. Vinh, "UFBoot2: Improving the ultrafast bootstrap approximation," Mol. Biol. Evol., vol. 35, no. 2, 2018, doi: 10.1093/molbev/msx281.

[12] B. Rumpe, Agile Modeling with UML. 2017. 